Supporting Information

\title{
Micellar Cobaltporphyrin Nanorods in Alcohols
}

\author{
Makoto Yuasa,* Kenichi Oyaizu, Aritomo Yamaguchi, and Michi Kuwakado
}

Department of Pure \& Applied Chemistry, Faculty of Science and Technology, Tokyo University of Science, Noda 278-8510, Japan, and Institute of Colloid and Interface Science, Tokyo University of Science, Tokyo 1628601, Japan

\section{1) General Methods}

Materials. All solvents were purified by distillation prior to use. Cobalt(II) acetate tetrahydrate was obtained from Aldrich Co., and recrystallized twice from $\mathrm{H}_{2} \mathrm{O}$. All other reagents were obtained from Kanto Chem. Co. or Tokyo Kasei Co. and used without further purification.

Synthesis. Synthesisn of CoTAPP was carried out according to the procedude involving three steps using 5,10,15,20-tetrakis(4-aminophenyl)-21H,23H-porphine (1) as a starting material.

5,10,15,20-Tetrakis(4-aminophenyl)-21H,23H-porphine (1). The compound 1 was prepared by the method described in the literature (Bettelheim, A.; White, B. A.; Raybuck, S. A.; Murray, R. W. Inorg. Chem. 1987, 26, 1009-1017) with slight modifications as follows. 4-Nitrobenzaldehyde $\left(22.0 \mathrm{~g}, 1.45 \times 10^{-1} \mathrm{~mol}\right)$ and acetic anhydride $\left(24.0 \mathrm{~mL}, 2.54 \times 10^{-1} \mathrm{~mol}\right)$ was dissolved in propionic acid $(600 \mathrm{~mL})$. The solution was then refluxed, to which pyrrole $\left(10.0 \mathrm{~mL}, 1.44 \times 10^{-1} \mathrm{~mol}\right)$ was slowly added. After refluxing for $30 \mathrm{~min}$, the resulting mixture was cooled to give a precipitate which was collected by filtration, washed with $\mathrm{H}_{2} \mathrm{O}$ and methanol, and dried under vacuum. The resulting powder was dissolved in pyridine $(160 \mathrm{~mL})$ which was refluxed for $1 \mathrm{~h}$. After cooling, the precipitate was collected by filtration and washed with acetone to give 5,10,15,20-tetrakis(4nitrophenyl)-21 $\mathrm{H}, 23 \mathrm{H}$-porphine as a purple crystal in $14 \%$ yield. The product $\left(4.13 \mathrm{~g}, 5.19 \times 10^{-3} \mathrm{~mol}\right)$ was dissolved in hot $\mathrm{HCl}(500 \mathrm{~mL})$ at $70^{\circ} \mathrm{C}$, to which was added $\mathrm{SnCl}_{2} \cdot 2 \mathrm{H}_{2} \mathrm{O}\left(18.0 \mathrm{~g}, 7.97 \times 10^{-2} \mathrm{~mol}\right)$. The resulting mixture was stirred at $70{ }^{\circ} \mathrm{C}$ for $30 \mathrm{~min}$ and then cooled to $0{ }^{\circ} \mathrm{C}$. After neutralization with aqueous $\mathrm{NH}_{3}$, the resulting gray crystalline product was collected by filtration and dissolved in acetone. Rotary evaporation of the solution followed by drying under vacuum yielded 1 as a purple crystal. Yield: $92 \%$. ${ }^{1} \mathrm{H} \mathrm{NMR}\left(\mathrm{CDCl}_{3}, 300\right.$ MHz, ppm): $\delta-2.7$ (s, 2H), 4.0 (s, 8H), 7.1-8.0 (m, 16H), 8.9 (s, 8H). MS (FAB, $m$-nitrobenzyl alcohol, $m / z)$ : Calcd for $\mathrm{M}+674.8$; Found 675. Anal. Calcd for $\mathrm{C}_{44} \mathrm{H}_{34} \mathrm{~N}_{8}$ : C, 78.31; H, 5.08; N, 16.61\%. Found: C, 77.88; $\mathrm{H}$, $5.29 ; \mathrm{N}, 16.30 \%$. UV-vis. $\left(\mathrm{CHCl}_{3}, \lambda_{\max }, \mathrm{nm}\right): 427,522,562,594,654$.

5,10,15,20-Tetrakis(4-hexadecylamidophenyl)-21H,23H-porphine (2). The compound $\mathbf{1}(500 \mathrm{mg}, 7.41 \times$ $\left.10^{-4} \mathrm{~mol}\right)$ was dissolved in $\mathrm{CHCl}_{3}(100 \mathrm{~mL})$ at $0-5{ }^{\circ} \mathrm{C}$, to which was slowly added $n$-heptadecanoyl chloride $\left(2.14 \mathrm{~g}, 7.41 \times 10^{-3} \mathrm{~mol}\right)$. The resulting mixture was stirred at $0-5{ }^{\circ} \mathrm{C}$ for $90 \mathrm{~min}$, and then at room temperature for 1 night. After addition of $\mathrm{CH}_{3} \mathrm{OH}(5 \mathrm{~mL})$ and further stirring for several hours, the resulting mixture was washed with $\mathrm{H}_{2} \mathrm{O}$, and the organic layer was rotary evaporated. Purification by recrystallization from $\mathrm{CHCl}_{3}-$ $\mathrm{CH}_{3} \mathrm{OH}$ followed by drying under vacuum yielded 2 as a purple crystal. Yield: $61 \%$. ${ }^{1} \mathrm{H}$ NMR $\left(\mathrm{CDCl}_{3}, 300\right.$ $\mathrm{MHz}, \mathrm{ppm}): \delta-2.9(\mathrm{~s}, 2 \mathrm{H}), 1.8-2.4(\mathrm{~m}, 132 \mathrm{H}), 7.6(\mathrm{~s}, 4 \mathrm{H}), 7.8-8.0(\mathrm{~m}, 16 \mathrm{H}), 8.8(\mathrm{~s}, 8 \mathrm{H})$. MS (FAB, $m-$ nitrobenzyl alcohol, $m / z$ ): Calcd for $\mathrm{M}+1684.6$; Found 1685. Anal. Calcd for $\mathrm{C}_{112} \mathrm{H}_{162} \mathrm{~N}_{8} \mathrm{O}_{4}$ : C, 79.85; H, 9.69; N, 6.65\%. Found: C, 78.83; H, 9.30; N, 7.10\%. UV-vis. $\left(\mathrm{CHCl}_{3}, \lambda_{\max }, \mathrm{nm}\right): 422,518,554,592,649$.

5,10,15,20-Tetrakis(4-hexadecylamidophenyl)porphyrinatocobalt(II) (CoTAPP). The ligand 2 (100 mg, $\left.6.84 \times 10^{-5} \mathrm{~mol}\right)$ and $\left(\mathrm{CH}_{3} \mathrm{COO}\right)_{2} \mathrm{Co} \cdot 4 \mathrm{H}_{2} \mathrm{O}\left(20.5 \mathrm{mg}, 8.20 \times 10^{-5} \mathrm{~mol}\right)$ was dissolved in DMF $(20 \mathrm{~mL})$, and the solution was refluxed for $1 \mathrm{~h}$ under argon. After cooling to room temperature, the resulting precipitate was collected by filtration, washed with $\mathrm{H}_{2} \mathrm{O}$ and $\mathrm{CH}_{3} \mathrm{OH}$, and dried under vacuum to yield CoTAPP as a red crystal. Yield: 84\%. Anal. Calcd for $\mathrm{C}_{112} \mathrm{H}_{160} \mathrm{~N}_{8} \mathrm{O}_{4} \mathrm{Co}$ : C, 77.24; H, 9.26; N, 6.44\%. Found: C, 77.89; H, 8.98; N, $6.68 \%$. UV-vis. $\left(\mathrm{CHCl}_{3}, \lambda_{\max }, \mathrm{nm}\right): 414,530$. 
Measurements. ${ }^{1} \mathrm{H}$ NMR spectra were recorded on a JEOL JNM Al-300 (300 MHz) spectrometer with chemical shifts downfield from tetramethylsilane as the internal standard. UV-vis spectra were recorded using a Shimadzu UV-2100 spectrometer. Elemental analyses were performed using a Perkin-Elmer PE-2400 II and a Metrohm 645 multi-DOSIMAT. Two parallel analyses were performed for each sample. Mass spectra were obtained using a JEOL JMS-SX102A spectrometer using $m$-nitrobenzyl alcohol as a matrix. Refractive index measurements were carried out using an Otsuka RM-102 refractometer at a wavelength of $633 \mathrm{~nm}$. Ultrasonic irradiation was carried out using a TOMY UD-200 ultrasonic disruptor $(35 \mathrm{~W})$. Static light scattering measurements were carried out using a Malvern 4700 Submicron Particle Analyzer with a Spectra-physics Model 127 He laser. Dynamic light scattering measurements were carried out using a NICOMP 380ZLS Particle Sizing System. Sample solutions were filtered prior to refractive index measurements and light scattering experiments using a syringe filter (PTFE filter media) with a pore size of $0.45 \mu \mathrm{m}$ from Whatman Inc. Electrochemical measurements were carried out in a conventional two-compartment cell. A 6 mm diameter edge-plane pyrolytic graphite disk was used as a working electrode. The auxiliary electrode, a coiled platinum wire, was separated from the working solution by a fine-porosity frit. The reference electrode was a commercial saturated calomel electrode, which was placed in the main cell compartment. All potentials are quoted with respect to this reference electrode. A Nikko Keisoku DPGS-1 dual potentiogalvanostat and a Hokuto Denko HB-104 universal programmer were employed with a Riken D-72DG X-Y recorder to obtain the voltammograms.

2) Results

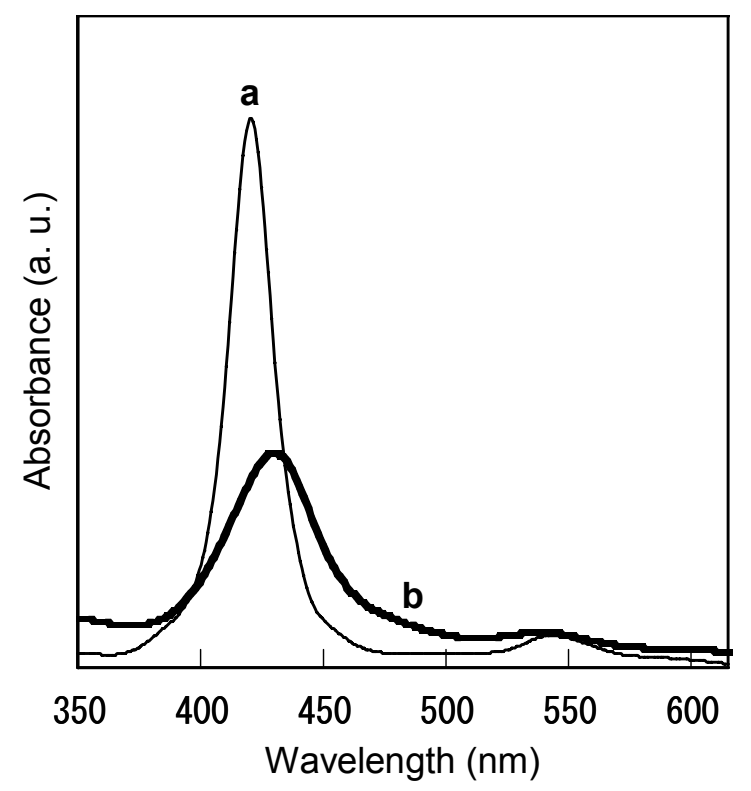

Figure S1. Absorption spectra of a pristine (unirradiated) solution of CoTAPP in ethanol/1-propanol 2/1 (v/v) (curve a) and the micellar solution of CoTAPP prepared by ultrasonic irradiation of the pristine solution for $6 \mathrm{~h}$ (curve b). The aggregation of CoTAPP resulted in a bathochromic shift of the Soret band ( $\lambda_{\max }$ : curve a, 414 ; curve $b$, $431 \mathrm{~nm})$ and a significant increase in the half-band width $\left(\Delta_{1 / 2}\right.$ : curve a, 19.6; curve b, $52.3 \mathrm{~nm})$. 


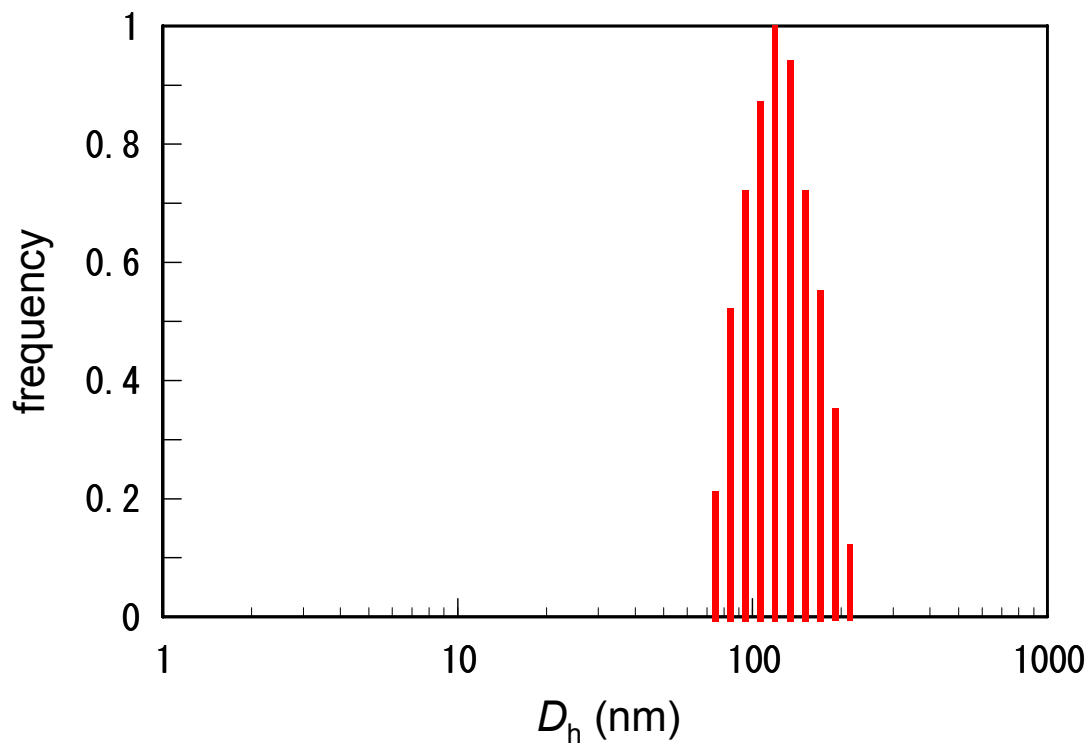

Figure S2. A DLS histogram of the micellar solution of CoTAPP in ethanol/1propanol 2/1 (v/v) after ultrasonic irradiation for $6 \mathrm{~h}$. Detection angle: $90^{\circ}$.

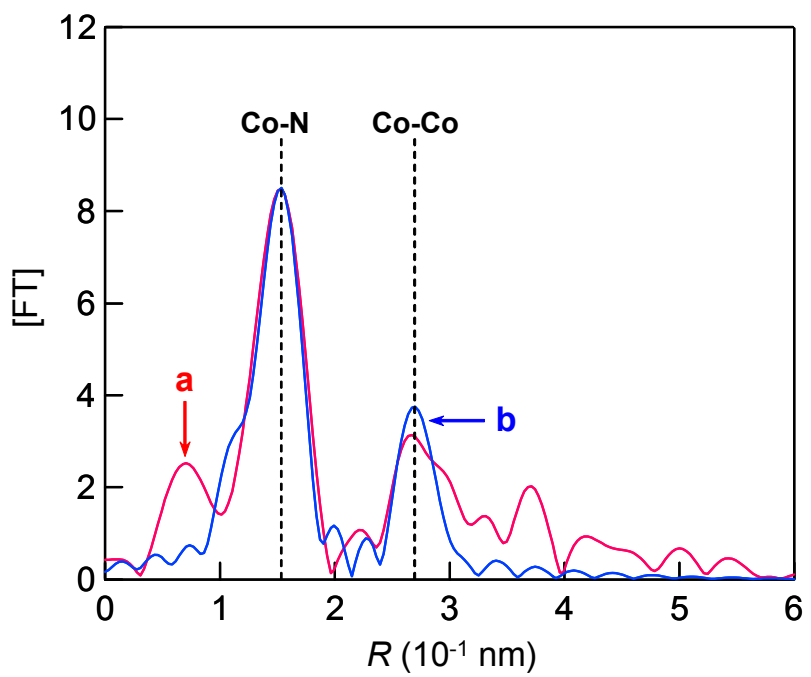

Figure S3. Fourier-transformed $k^{3}$-weighted EXAFS function for the micellar solution of CoTAPP in ethanol/1-propanol 2/1 (v/v) after ultrasonic irradiation for $6 \mathrm{~h}$ (curve a), and the simulated function (curve b) obtained by curve-fitting calculations using the FEFF8 code (Ankudinov, A. L.; Ravel, B.; Rehr, J. J.; Conradson, S. D. Phys. Rev. B 1998, 58, 7565). The simulated curve corresponded to atomic distances of $R_{\mathrm{Co}-\mathrm{N}}=$ $0.196 \pm 0.001 \mathrm{~nm}$ and $R_{\mathrm{Co}-\mathrm{Co}}=0.303 \pm 0.001 \mathrm{~nm}$, and coordination numbers of $N_{\mathrm{Co}-\mathrm{N}}=$ $4.4 \pm 0.57$ and $N_{\mathrm{Co}-\mathrm{Co}}=0.9 \pm 0.86$. 